ISSN: 2302-8556

\title{
Pengaruh Sikap dan Motivasi terhadap Minat Mahasiswa untuk Mengikuti Pendidikan Profesi Akuntan (PPAk)
}

\author{
Ni Made Anita Dewi Natami ${ }^{1}$ \\ Ketut Muliartha ${ }^{2}$ \\ ${ }^{1,2}$ Fakultas Ekonomi dan Bisnis Universitas Udayana (Unud), Bali, Indonesia \\ e-mail: anita_natami@yahoo.com
}

\begin{abstract}
ABSTRAK
Mengetahui pengaruh sikap, motivasi kualitas, dan motivasi ekonomi terhadap minat mahasiswa untuk mengikuti PPAk merupakan tujuan dari penelitian ini. Lokasi peneitian ini adalah Fakultas Ekonomi dan Bisnis (FEB) Universitas Udayana. Sampel penelitian ini terdiri atas 170 mahasiswa angkatan 2015 jurusan akuntansi, dimana 87 orang mahasiswa reguler dan 83 orang mahasiswa non reguler. Teknik sampling yang digunakan adalah purposive sampling dengan menggunakan rumus solvin. Pengumpulan data yang digunakan adalah menggunakan kusioner. Teknik analisis data yang digunakan dalam penelitian ini yaitu analisis regresi linear berganda. Hasil analisis data menemukan bahwa sikap, motivasi kualitas, dan motivasi ekonomi berpengaruh positif terhadap minat mahasiswa untuk mengikuti program PPAk.
\end{abstract}

Kata kunci : Sikap; Motivasi Kualitas; Motivasi Ekonomi; Minat Mengikuti PPAk.

\begin{abstract}
Knowing the influence of attitudes, quality motivation, and economic motivation on students' interest in joining PPAk is the purpose of this study. The research location is the Faculty of Economics and Business (FEB), Udayana University. The study sample consisted of 1702015 class students majoring in accounting, of which 87 were regular students and 83 were non-regular students. The sampling technique used was purposive sampling using solvin formula. The data collection used is using questionnaires. Multiple linear regression analysis is the data analysis technique that used in this study. The results of data analysis found that attitudes, quality motivation, and economic motivation had a positive effect on students' interest in joining PPAk.

Keywords: Attitudes; Quality Motivation; Economic Motivation; Interest in Following PPAk
\end{abstract}

\section{PENDAHULUAN}

Adanya perubahan pada sistem pendidikan khususnya pendidikan akuntansi di Indonesia, mengharuskan lulusan sarjana akuntansi harus mengikuti Pendidikan Profesi Akuntansi atau PPAk untuk mendapatkan gelar akuntan. Mahasiswa yang sedang menjalani kuliah jurusan akuntansi dan berniat ingin memiliki gelar akuntan, harus mengikuti PPAk setelah lulus dari jenjang strata satu. Benny 
Ni Made Anita Dwi Natami dan Ketut Muliartha. Pengaruh ...

(2006) mahasiswa yang menentukan pilihannya untuk kuliah di jurusan akuntansi kebanyakan memiliki motivasi untuk menjadi ahli dan professional di bidang akuntansi. Keinginan untuk menjadi professional di bidang akuntansi dengan alasan bahwa banyak perusahaan yang akan membutuhkan tenaga akuntan.

Fakultas Ekonomi dan Bisnis Universitas Udayana memiliki Program Pendidikan Profesi Akuntan di Fakultas Ekonomi dan Bisnis Universitas Udayana (PPAk FEB Unud) dan telah memiliki surat izin Penyelenggaraan Program Pendidikan Profesi dari Kementerian Pendidikan dan Kebudayaan Direktorat Jenderal Pendidikan Tinggi No.3827/D/T/2003, tertanggal 20 November 2003. Pada Tabel 1 dijabarkan mengenai perkembangan mahasiswa PPAk FEB Universitas Udayana selama periode 2014-2018.

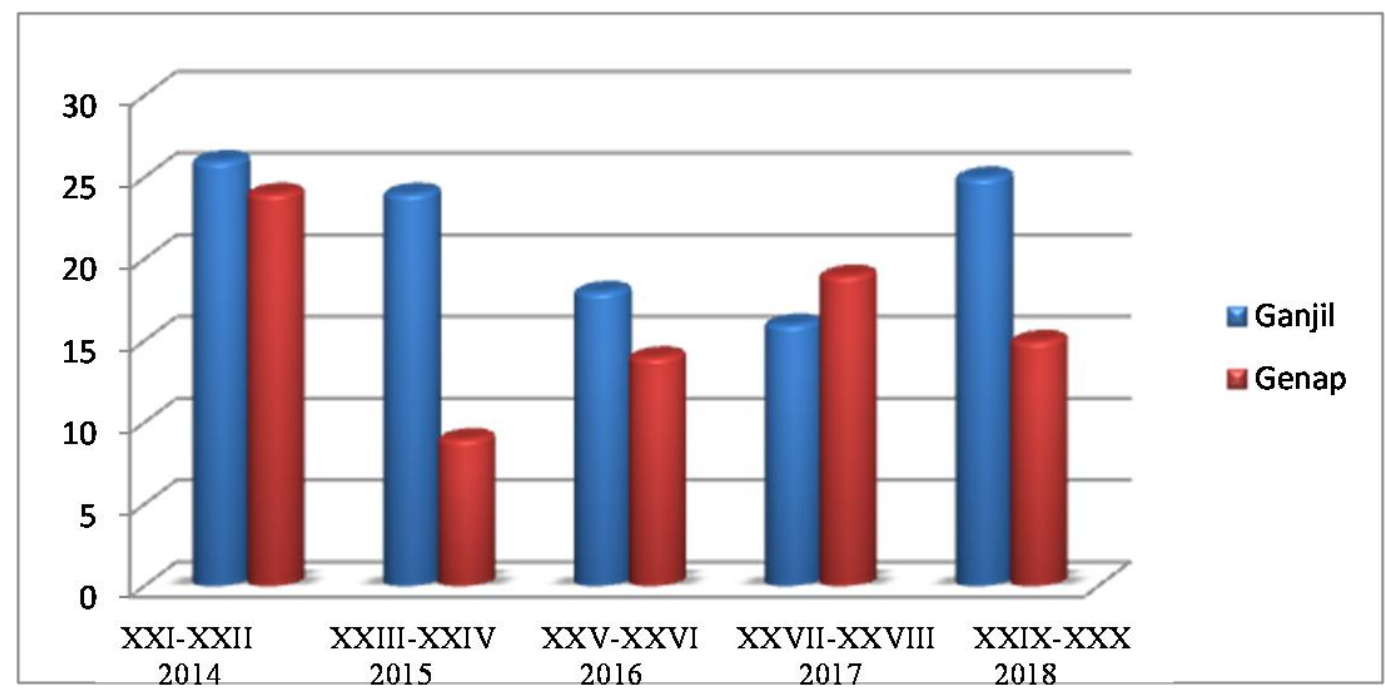

Gambar 1. Perkembangan Jumlah Mahasiswa PPAk FEB Universitas Udayana

Sumber: Fakultas Ekonomi dan Bisnis Universitas Udayana, 2018

Dipaparkan bahwa pada angkatan XXI dan XXIII terjadi peningkatan jumlah mahasiswa. Sedangkan dari angkatan XXIV sampai XXIX mengalami naik turun atau fluktuasi jumlah mahasiswa. Berbeda dengan angkatan XXX 
mengalami penurunan jumlah mahasiswa PPAk. Ini terlihat bahwa minat seorang mahasiswa untuk mengkuti PPAk masih rendah.

Dorongan seorang mahasiswa untuk memilih melanjutkan ke PPAk dapat didorong oleh beberapa hal seperti sikap, motivasi kualitas, serta motivasi ekonomi. Mahasiswa yang memilih untuk melanjutkan ke jenjang PPAk telah memiliki sikap dan minat serta telah memutuskan untuk menjalani PPAk setelah masa kuliahnya selesai. Sikap termasuk faktor internal dari dalam diri sendiri yang kemudian mempengaruhi keputusan yang akan dibuat. Menurut Wirawan (1996:94) sikap adalah bagaimana seseorang siap untuk merespon hal-hal tertentu. Menurut Robins dan Judge (2015) motivasi adalah rangkaian atau proses dari usaha seseorang untuk mencapai tujuan yang telah ditetapkan. Motivasi adalah keinginan dari individu untuk mencapai sebuah tujuan dengan melakukan hal-hal tertentu (Istina dan Yulita, 2014).

Minat juga menjadi faktor yang penting. Menurut Slameto (2010:180) minat adalah ketika individu memiliki rasa ketertarikan terhadap sesuatu tanpa dipengaruhi oleh orang lain. Ketika seseorang menginginkan sesuatu didasari oleh keinginan setelah melihat, melakukan observasi, serta telah melakukan pembandingan dan sudah dipertimbangkan sesuai kebutuhan yang diinginkannya disebut dengan minat (Widyastuti dkk, 2004)

Jumalh akuntan di Indonesia masih sedikit jika dibandingkan dengan akuntan asing di Asia Tenggara hal ini menyebabkan perlunya usaha yang lebih besar dari Ikatan Akuntan Indoensia (IAI) untuk mensertifikasi lebih banyak 
Ni Made Anita Dwi Natami dan Ketut Muliartha. Pengaruh ...

akuntan untuk mendapatkan lebih banyak akuntan yang professional (www.kompas.com).

Terdapat tiga faktor yang menentukan perilaku (Ajzen, 1991) yaitu pertama sikap terhadap perilaku, individu memiliki keyakinan perilaku behavioral beliefs atau bahwa akan terdapat hasil dari suatu perilaku atau beliefs strength and outcome evaluation. Faktor yang kedua adalah keyakinan normatif yaitu dalam mewujudkan suatu harapan individu memiliki keyakinan mengenai harapan normative dari individu lain yang kemudian mendorong atau memberi motivasi bagi individu tersebut untuk mewujudkan harapan tersebut atau normative beliefs and motivation to comply. Dari keyakinan normatif maka akan ada norma subjektif atau subjectivenorms. Ketika individu membentuk suatu perilaku seseorang akan memiliki anggapan mengenai efek social dari perbuatan tersebut. Ketiga adalah kontrol perilaku yang dipersepsikan yaitu individu memiliki keyakinan mengenai faktor-faktor yang dapat memberi dukungan maupun memberi hambatan dari perilaku individu tersebut.

Teori Kebutuhan McClelland diantaranya adalah. Kebutuhan yang pertama adalah individu perlu untuk mencapai kesuksesan atau need for achievement. Kebutuhan yang kedua adalah individu memerlukan koneksi atau hubungan yang baik dengan individu lain atau need for affiliation. Kebutuhan yang ketiga adalah individu merasa memerlukan suatu kekuasaan yang digunakan untuck mengendalikan individu lain atau need for power.

Menurut Teori ini terdapat 5 tingkatan hirarki kebutuhan hidup manusia yaitu pertama kebutuhan fisiologis atau physiological needs, yaitu manusia 
memiliki kebutuhan untuk makan, minum,kebutuhan akan udara, kebutuhan akan air, kebutuhan akan pakaian, kebutuhan akan adanya tempat berlindung yaitu tempat tinggal serta manusia perlu mempertahankan hidupnya. Tingkatan hirarki yang kedua adalah kebutuhan keamanan atau safety needs, yaitu manusia memiliki kebutuhan untuk melindungi dirinya dari berbagai macam ancaman baik ancaman fisik maupun mental dan menginginkan rasa aman. Tingkatan hirarki yang ketiga adalah kebutuhan sosial atau social needs, yaitu manusia memerlukan rasa kasih saying dan perlu untuk memberikan rasa sayangnya kepada mahluk lain karena manusia adalah mahluk sosial. Tingkatan hirarki yang keempat adalah kebutuhan penghargaan atau esteem needs, pada tingkatan keempat ini dianggap bahwa manusia telah mencapai ketiga tingkatan hirarki sebelumnya sehingga tahap selanjutnya manusia menginginkan pengakuan dari manusia lainnya. Tingkatan hirarki yang terakhir adalah kebutuhan aktualisasi diri atau self actualization, ketika manusia telah memenuhi keempat hirarki yang sebelumnya telah disebutkan manusia akan memiliki ambisi lain yaitu aktualisasi diri. Manusia akan berambisi untuk memenuhi ambisi pribadinya.

PPAk merupakan pendidikan tambahan pada pendidikan tinggi setelah seseorang menyelesaikan program sarjana Ilmu Ekonomi dalam program studi akuntansi. Memiliki akuntantan yang terstandarisasi dan memiliki kualitas yang baik serta professional di Indonesia merupakan misi dari diadakannya program PPAk. International Financial Accounting Committe (IFAC) telah menentukan beberapa persyaratan untuk bisa dikategorikan sebagai akuntan yang profesinal. Oleh karena itu segala kelengkapan mengenai pembelanjaran materi PPAk telah 
Ni Made Anita Dwi Natami dan Ketut Muliartha. Pengaruh ...

disesuaikan dengan aturan agar memenuhi syarat sebagai akuntan professional yang dibuat oleh IFAC.

Menurut Besterfield (2003) kualitas adalah berbagai jenis karakteristik yang memiliki tingkatan-tingkatan dan memenuhi ukuran tertentu. Goetsch (2002) memiliki pendapat bahwa kualitas merupakan keadaan dinamis yang berkaitan dengan produk, jasa, SDM, serangkaian proses, dan lingkungan yang memenuhi atau melebihi harapan atau standar.

Motivasi ekonomi adalah keetika seseorang berpikiran untuk meningkatkan kemampuan dalam dirinya yang didasari oleh pikiran bahwa dengan dilakukannya peningkatan tersebut maka penghargaan finansial yang diharapkan juga akan meningkat. Penghargaan finansial dapat dikategorikan menjadi dua kategori yaitu penghargaan finansial langsung dan penghargaan finansial tidak langsung.

Sikap merupakan bagaimana individu percaya tentang adanya konsekuensi dari setiap perilaku atau behavioral belief dan bagaimana seseorang mengevaluasi mengenai konsepuensi apa yang akan didapatkan yang merupakan hasil dari perilakunya atau outcome evaluation (Hartono, 2007:38).

Menurut Slameto (2010:180) minat adalah ketika individu memiliki rasa ketertarikan terhadap sesuatu tanpa dipengaruhi oleh orang lain. Ketika seseorang menginginkan sesuatu didasari oleh keinginan setelah melihat, melakukan observasi, serta telah melakukan pembandingan dan sudah dipertimbangkan sesuai kebutuhan yang diinginkannya disebut dengan minat (Widyastuti dkk, 2004) 
Kecerdasan emosional dapat dikatakan sebagai bagian dari sikap. Individu yang dapat memanfaatkan energinya kearah yang lebih positif dan menghasil sesuatu atau produktif lebih memiliki motivasi untuk mengimprovisasi dirinya menjadi lebih baik. Segala usaha yang dilakukan oleh individu dalam meraih prestasi dan tujuan yang ditetapkan akan didukung oleh kecerdasan emosional dan minat (Chinowsky P. dan Carillo P., 2006). Kualitas sumber daya manusia dapat ditingkatkan dengan meningkatkan kecerdasan emosional yang dimiliki oleh individu karena seseorang yang memiliki kecerdasan emosional yang tinggi cenderung bekerja dengan lebih efektif dan efisien (Solikhah, 2014). Cendrawi (2015) dalam penelitiannya mengenai norma subjektif menemukan bahwa adanya pengaruh yang positif dari norma subjektif terhadap minat berkarir mahasiswa. Cendrawi(2015) dalam penelitiannya mengenai kontrol perilaku menemukan bahwa kontrol perilaku memilki pengaruh yang positif terhadap minat mahasiswa. Felton et al., (1995) menemukan adanya pengaruh positif dari sikap pada pengambilan keputusan mahasiswa untuk melanjutkan ke jenjang PPAk. Hipotesis satu dari penelitian ini adalah:

$\mathrm{H}_{1}$ : Sikap berpengaruh positif terhadap minat mahasiswa untuk mengikuti Pendidikan Profesi Akuntan.

Menurut Besterfield (2003) kualitas adalah berbagai jenis karakteristik yang memiliki tingkatan-tingkatan dan memenuhi ukuran tertentu. Goetsch (2002) memiliki pendapat bahwa kualitas merupakan keadaan dinamis yang berkaitan dengan produk, jasa, SDM, sserangkaian proses, dan lingkungan yang memenuhi atau melebihi harapan atau standar. 
Ni Made Anita Dwi Natami dan Ketut Muliartha. Pengaruh ...

Teori David McClelland (Robins dan Judge, 2008:87) mengemukakan adanya dorongan bagi manusia untuk memilki sebuah prestasi. Thomas et al., (1998) menemukan adanya hubungan yang kuat antara tingkat Continuing Professional Education atau CPE dengan kualitas dari kinerja. Tella (2007) menyatakan peningkatan kualitas dan prestasi menjadi salah satu alasan seseorang menentukan keputusan bahwa akan melanjutkan ke pendidikan selanjutnya. Penelitian Novita (2009) yang menemukan adanya pengaruh positif antara motivasi kualitas terhadap minat mahasiswa untuk mengikuti PPAk. Penelitian selanjutnya Widyastuti (2004) yang menyatakan bahwa motivasi kualitas memiliki pengaruh yang positif terhadap minat mahasiswa untuk mengikuti PPAk itu, begitu juga dengan penelitian Ikbal (2011) dan Kusumastuti (2013) yang menemukan adanyaa pengaruh yang postif dari kedua variabel tersebut. Hipotesis dua penelitian ini adalah:

$\mathrm{H}_{2}$ : Motivasi Kualitas berpengaruh positif pada minat mahasiswa mengikuti Pendidikan Profesi Akuntan.

Stole, S. D., (1976) menyatakan bahwa KAP cenderung memberikan banyak pengalaman kerja serta reward secara finansial yang diberikan oleh KAP terbilang cukup baik. Sesuai dengan penelitian ditemukan bahwa gaji menjadi salah satu faktor penentu bagi seseorang dalam mengambil keputusan. Mahasiswa yang memilih untuk berprofesi sebagai akuntan lebih mempertimbangkan penghargaan finansial gaji jangka panjang dan kesempatan kerja yang lebih menjanjikan. Hasil penelitian Meitiyah (2014) dan Ikbal (2011) menemukan bahwa variabel motivasi memiliki pengaruh yang positif terhadap minat dari 
individu yaitu mahasiswa untuk memutuskan mengikuti program PPAk. Hipotesis tiga dari penelitian ini adalah:

$\mathrm{H}_{3}$ : Motivasi ekonomi berpengaruh positif pada minat mahasiswa mengikuti Pendidikan Profesi Akuntan.

\section{METODE PENELITIAN}

Fakultas Ekonomi dan Bisnis Universitas Udayana merupakan lokasi yang dipilih untuk penelitian ini karena hanya FEB Universitas Udayana yang memiliki program PPAk di wilayah Bali. Adapun objek dalam penelitian ini adalah sikap, motivasi kualitas, motivasi ekonomi, serta minat mahasiswa untuk mengikuti PPAk. Sikap merupakan bagaimana individu percaya tentang adanya konsekuensi dari setiap perilaku atau behavioral belief dan bagaimana seseorang mengevaluasi mengenai konsepuensi apa yang akan didapatkan yang merupakan hasil dari perilakunya atau outcome evaluation (Hartono, 2007:38). Indikator yang digunakan sesuai denga yang digunakan oleh Solikhah(2014) dalam penelitiannya adalah pertama ada tidaknya lapangan pekerjaan, kedua adalah kualitas jaminan hidup, ketiga adalah bagaimana persepsi dari pekerjaan seorang akuntan, dan terakhir bagaimana peningkatan prestige di masyarakat

Menurut Besterfield (2003) kualitas adalah berbagai jenis karakteristik yang memiliki tingkatan-tingkatan dan memenuhi ukuran tertentu. Goetsch (2002) memiliki pendapat bahwa kualitas merupakan keadaan dinamis yang berkaitan dengan produk, jasa, SDM, serangkaian proses, dan lingkungan yang memenuhi atau melebihi harapan atau standar. Instrumen pernyataan yang diadopsi dari kusionerKusumastuti (2013) digunakan untuk mengukur motivasi kualitas. 
Ni Made Anita Dwi Natami dan Ketut Muliartha. Pengaruh ...

Variabel indikator yang digunakan meliputi pengetahuan dalam bidang perpajakan, auditing, keuangan, dan akuntansi manajemen, pemahaman mengenai lingkungan bisnis, keahlian dalam mengaplikasikan pengetahuan akuntansi, perkembangan kebijakan akuntansi terkini, kemampuan interpersonal seperti kemampuan bekerjasama dalam kelompok, menyelesaikan masalah, dan berkomunikasi.

Motivasi ekonomi adalah keetika seseorang berpikiran untuk meningkatkan kemampuan dalam dirinya yang didasari oleh pikiran bahwa dengan dilakukannya peningkatan tersebut maka penghargaan finansial yang diharapkan juga akan meningkat. Penghargaan finansial dapat dikategorikan menjadi dua kategori yaitu penghargaan finansial langsung dan penghargaan finansial tidak langsung.

Instrumen pernyataan yang diadopsi dari kusioner Kusumastuti (2013) digunakan untuk mengukur motivasi ekonomi. Varibael indikator yang digunakan meliputi gaji jangka panjang yang besar, pekerjaan dengan fasilitas memadai, tunjangan yang baik, gaji tambahan yang tinggi, adanya kenaikan gaji dan gaji awal tinggi, pekerjaan yang menyediakan program bagi pensiunan.

Menurut Kamus Besar Bahasa Indonesia (2008:1027) minat adalah kecenderungan hati yang tinggi terhadap seseuatu hal, hal dalam pengertian ini berarti kegairahan dan kecenderungan hati untuk mengikuti PPAk. Instrumen pernyataan yang diadopsi dari kuesioner Hadiprasetyo (2014) digunakan untuk mengukur minat mengikuti PPAk. Variabel indikator yang digunakan meliputi tertarik akan adanya peningkatan kualitas calon akuntan, tertarik akan baiknya 
jenjang kaarir yang akan membawa kesuksesan dalam profesi akuntan, adanya rasa ingin memiliki pekerjaan dengan gaji atau pembayaran secara finansial yang besar, pertimbangan lainnya yang menjadi dasar dari rasa tertarik memasuki program PPAk. Variabel sikap, motivasi kualitas, motivasi ekonomi, dan minat diukur dengan menggunakan skala likert 4 poin.

Populasi dalam penelitian ini adalah sejuhmlah 294 mahasiswa akuntansi program S1 reguler dan non reguler angkatan 2015 di FEB Universitas Udayana. Teknik pengambilan sampel yang digunakan adalah teknik purposive sampling dengan menggunakan rumus solvin. Sampel dalam penelitian ini berjumlah 170 orang mahasiswa jurusan akuntansi, dimana 87 orang mahasiswa reguler dan 83 orang mahasiswa non reguler. Kriteria dalam pengambilan sampel yaitu mahasiswa semester VII dan sudah mengambil mata kuliah Pengauditan dengan asumsi mereka sudah memiliki pengalaman yang memadai mengenai karir dibidang akuntansi dan sudah memiliki perencanaan karir setelah selesai menempuh perkuliahan S1. Kuisioner merupakan metode pengumpulan data yang digunakan. Kuisioner disebarkan pada semua mahasiswa akuntansi program S1 reguler dan non reguler angkatan 2015 di Fakultas Ekonomi dan Bisnis Universitas Udayana.

\section{HASIL DAN PEMBAHASAN}

Responden dalam penelitian ini adalah mahasiswa program S1 reguler dan non reguler jurusan akuntansi angkatan 2015. Kuesioner yang disebar ke responden sejumlah 170 kuesioner dan responden mengisi kuesioner tersebut dengan lengkap 
Ni Made Anita Dwi Natami dan Ketut Muliartha. Pengaruh ...

sesuai dengan prosedur pengisian kuesioner. Semua kuesioner yang layak digunakan untuk analisis selanjutnya adalah 170 kusioner dengan tingkat pengembalian $100 \%$.

Jenis kelamin dan angkatan menjadi karakteristik dari responden yang diteliti dalam penelitian ini dan dapat dilihat pada Tabel 1.

Tabel 1.

Karakteristik Responden

\begin{tabular}{|c|c|c|c|}
\hline \multirow[t]{2}{*}{ No. } & \multirow[t]{2}{*}{ Karakteristik Responden } & \multicolumn{2}{|c|}{ Jumlah } \\
\hline & & Orang & Persentase (\%) \\
\hline \multirow[t]{4}{*}{1.} & Jenis Kelamin & & \\
\hline & Pria & 69 & 41 \\
\hline & Wanita & 101 & 59 \\
\hline & Total & 170 & 100 \\
\hline \multirow[t]{3}{*}{2} & Angkatan & & \\
\hline & 2015 & 170 & 100 \\
\hline & Total & 170 & 100 \\
\hline
\end{tabular}

Perbedaan dari jenis kelamin dapat mempengaruhi keputusan yang akan diambil. Jenis kelamin mempengaruhi secara emosional. Dapat dilihat pada Tabel 1, responden dengan jenis kelamin wanita yaitu 101 orang atau 59\% dari total responden dan responden yang berjenis kelamin laki-laki adalah 69 orang atau $41 \%$ dari total responden. Angkatan responden digunakan sebagai indikator untuk mengetahui tingkat pengetahuan dan intelektualitas yang dimiliki oleh responden. Berdasarkan Tabel 1 dapat dilihat bahwa angkatan 2015 sebanyak 170 orang responden $(100 \%)$.

Untuk mengetahui korelasi antara skor tiap butir pertanyaan dlam kuisioner yang digunakan maka harus dilakukan uji validitas. Hasil dari uji validitas untuk penelitian ini didapatkan bahwa instrument yang digunakan dalam penelitian ini 
memiliki nilai koefisien korelasi yang melebihi 0,30 yang memiliki arti bahwa tiap butir pertanyaan yang digunakan dalam penelitian ini adalah valid.

Uji Realiabilitas dilakukan jika memberikan hasil yang konsisten bila dilakukan dengan gejala yang sama sehingga diperoleh nilai Cronbach's Alpha. Hasil uji reabilitas bisa dilihat pada Tabel 2, sebagai berikut.

Tabel 2.

Hasil Uji Reliabilitas

\begin{tabular}{clll}
\hline & & & \\
No & Variabel & Cronbach's Alpha & Keterangan \\
& & & \\
\hline 1 & Sikap (X1) & 0,928 & Reliabel \\
2 & MotivasiKualitas (X2) & 0,949 & Reliabel \\
3 & MotivasiEkonomi(X3) & 0,950 & Reliabel \\
4 & MinatMengikuti PPAK (Y) & 0,923 & Reliabel \\
\hline
\end{tabular}

Sumber: Data diolah, 2019

Berdasarkan Tabel 2 dapat disimpulkan bahwa nilai cronbach's alpha pada setiap variabel telah melebihi 0,60 . Hal ini menunjukkan bahwa seluruh pernyataan dalam kuesioner penelitian ini reliable dan dapat digunakan untuk melakukan penelitian.

Statistik deskriptif yang disajikan dalam penelitian ini adalah untuk memberikan informasi perihal karakteristik variable penelitian, antara lain: nilai minimum, nilai maksimum, rata-rata, dan standar deviasi dengan $\mathrm{N}$ yang merupakan jumlah responden penelitian. Hasil Statistik Deskriptif dapat dilihat pada Tabel 3, sebagai berikut. 
Tabel 3.

Hasil Statistik Deskriptif

\begin{tabular}{lrrrrr}
\hline & N & Minimum & Maximum & Mean & Std. Deviation \\
\hline Sikap & 170 & 10 & 32 & 25,94 & 4,455 \\
Motivasi Kualitas & 170 & 11 & 36 & 29,16 & 5,026 \\
Motivasi Ekonomi & 170 & 10 & 28 & 22,90 & 4,213 \\
Minat Mengikuti PPAK & 170 & 6 & 20 & 16,79 & 2,812 \\
Valid N (listwise) & 170 & & & & \\
\hline
\end{tabular}

Sumber: Data diolah, 2019

Dapat dijelaskan hasil dari uji statistik deskriptif pada Tabel yaitu berdasarkan

Tabel 3 total sampel yang digunakan adalah 170 responden. Variabel sikap memiliki nilai minimum 10, nilai maksimum 32 dan nilai rata-rata sebesar 25,94.

Nilai standar deviasi variabel sikap yaitu 4,455 dan nilai standar deviasi kurang dari nilai rata-rata, yang artinya sebaran data terkait sikap sudah merata.

Berdasarkan Tabel 3 total sampel yang digunakan adalah 170 responden. Nilai minimum dari variabel motivasi kualitas adalah 11 dan nilai maksimumnya adalah 36. Rata-rata dari variabel motivasi kualitas adalah 29,16 . Nilai standar deviasi variabel motivasi kualitas sebesar 5,026 dan standar deviasi lebih rendah dibandingkan dengan nilai rata-rata, yang artinya sebaran data terkait motivasi kualitas sudah merata.

Berdasarkan Tabel 3 total sampel yang digunakan adalah 170 responden. Variabel motivasi ekonomi memiliki nilai minimum 10, nilai maksimum 28 dan nilai rata-rata sebesar 22,90. Nilai standar deviasi variabel motivasi ekonomi4,213 dan standar deviasi lebih rendah dibandingkan dengan nilai rata-rata, yang artinya sebaran data terkait motivasi ekonomi sudah merata.

Berdasarkan Tabel 3 total sampel yang digunakan adalah 170 responden. Nilai minimum dari variabel minat mengikuti PPAk adalah 6 dan nilai maksimum dar variabel minat mengikuti PPAk adalah 20. Nilai rata-rata dari variabel minat 
mengikuti PPAk adalah 16,79. Nilai standar deviasi variabel minat mengikuti PPAk 2,812 dan standar deviasi lebih rendah dibandingkan dengan nilai rata-rata, yang artinya sebaran data terkait minat mengikuti PPAk sudah merata.

Uji Normalitas bertujuan untuk menguji apakah dalam sebuah model regresi, variable residual atau variable pengganggu memiliki distribusi normal atau tidak. Hasil uji normalitas dapat dilihat pada Tabel 4, sebagai berikut.

Tabel 4.

Hasil Uji Normalitas

\begin{tabular}{llr}
\hline & & $\begin{array}{c}\text { Unstandardized } \\
\text { Residual }\end{array}$ \\
\hline $\mathrm{N}$ & & 170 \\
Normal Parameters & &, 00000000 \\
& Mean & 1,819712026 \\
Most Extreme Differences & Std. Deviation &, 089 \\
& Absolute &, 089 \\
& Positive &,- 051 \\
Kolmogorov-Smirnov Z & Negative & 1,162 \\
Asymp. Sig. (2-tailed) & &, 134 \\
\hline Sumber: Data diolah, 2019 & &
\end{tabular}

Berdasarkan Tabel 4 dapat dilihat bahwa nilai Asymp.Sig. (2-tailed) sebesar 0,134 lebih besar dari $\alpha=0,05$ yang berarti model telah berdistribusi normal

Uji Multikolinearitas dilakukan untuk mengetahui korelasi dari tiap variabel bebas. Jika nilai tolerance lebih besar dari $0,10(>0,10)$ atau nilai VIF kurang dari $10(<10)$, maka model dapat dikatakan bebas dari terjadinya multikolinearitas. Hasil Uji multikolinearitas dapat dilihat pada Tabel 5 sebagai berikut.

Tabel 5.

Hasil Uji Multikolinearitas

\begin{tabular}{llrr}
\hline & & \multicolumn{2}{c}{ Collinearity Statistics } \\
\cline { 3 - 4 } Model & (Constant) & Tolerance & VIF \\
\hline 1 & &, 325 & 3,080 \\
& Sikap &, 314 & 3,190 \\
& Motivasi Kualitas &, 401 & 2,497 \\
\hline
\end{tabular}

Sumber: Data diolah, 2019 
Ni Made Anita Dwi Natami dan Ketut Muliartha. Pengaruh ...

Dapat dilihat pada Tabel bahwa semua variabel bebas mempunya nilai tolerance yang melebihi 0,1 atau dapat dilihat dari nilai VIF tiap variabel bebas yang lebih rendah dari 10 . Hal ini berartti bahwa pada model regresi tidak terjadi gejala multikolinearitas.

Uji Heteroskedastisitas dilakukan untuk menguji apakah dalam model regresi terjadi ketidaksamaan varian residu satu pengamatan ke pengamatan lain. Apabila model suatu regresi mengandung gejalaheteroskedastisitas, maka hasil yang diberikan akan menyimpang. Jika probabilitas siginifikansinya di atas 0,05 maka dapat dikatakan bahwa pada model regresi bebas dari heteroskedastisitas. Berikut disajikan pada Tabel 6 mengenai hasil uji heteroskedastisitas.

Tabel 6.

Hasil Uji Heteroskedastisitas

\begin{tabular}{llr} 
Model & & Sig. \\
\hline 1 & (Constant) &, 000 \\
& Sikap &, 935 \\
& Motivasi Kualitas &, 444 \\
& Motivasi Ekonomi &, 072 \\
\hline Sumber: & Data diolah, 2019 &
\end{tabular}

Berdasarkan Tabel 6, menunjukkan bahwa nilai Sig. tiap variabel melebihi 0,05 sehingga semua variabel yang digunakan dalam penelitian ini dapat dikatakan bebas dari masalah heteroskedastisitas.

Analisis regresi linier berganda digunakan untuk menguji pengaruh variabel sikap, motivasi ekonomi, motivasi kualitas, terhadap minat mahasiswa mengikuti PPAk. Tabel 7 menyajikan hasil dari analisis linier berganda, sebagai berikut. 
Tabel 7.

Hasil analisis regresi linier berganda

\begin{tabular}{|c|c|c|c|c|c|c|}
\hline \multirow[b]{2}{*}{ Mode } & & \multicolumn{2}{|c|}{$\begin{array}{l}\text { Unstandardized } \\
\text { Coefficients }\end{array}$} & $\begin{array}{l}\text { Standardized } \\
\text { Coefficients }\end{array}$ & \multirow[b]{2}{*}{$\mathrm{T}$} & \multirow[b]{2}{*}{ Sig. } \\
\hline & & $\mathrm{B}$ & Std. Error & Beta & & \\
\hline \multirow[t]{6}{*}{1} & (Constant) & 3,431 & ,891 & & 3,849 &, 000 \\
\hline & Sikap & ,210 &, 056 & ,333 & 3,773 & ,000 \\
\hline & Motivasi &, 154 &, 050 & ,276 & 3,073 & ,002 \\
\hline & Kualitas & & & & & \\
\hline & Motivasi & , 149 & ,053 & ,223 & 2,815 &, 005 \\
\hline & Ekonomi & & & & & \\
\hline
\end{tabular}

Sumber: Data diolah, 2019

Berdasarkan Tabel 7 , diperoleh suatu persamaan regresi sebagai berikut:

$$
Y=3,431+0,210 X_{1}+0,154 X_{2}+0,149 X_{3}+\varepsilon
$$

Berdasarkan persamaan regresi diatas, dapat diinterpretasikan sebagai berikut, nilai konstanta $(\alpha)$ menunjukkan nilai positif sebesar 3,431menyatakan bahwa jika variabel independen dalam penelitian ini konstan pada angka nol, maka nilai variabel dependen yaitu minat mengikuti PPAK (Y) yaitu 3,431. $\beta_{1}$ yaitu variabel sikap memiliki nilai 0,210 , artinya apabila nilai variabel sikap mengalami kenaikan 1\%, maka minat mengikuti PPAK akan mengalami peningkatan sebesar $21 \%$ dengan asumsi nilai variabel independen lainnya tidak berubah (konstan). Koefisien variabel motivasi kualitas $\left(\beta_{2}\right)$ sebesar 0,154 , artinya apabila nilai variabel motivasi kualitas mengalami kenaikan 1\%, maka minat mengikuti PPAK akan mengalami peningkatan sebesar $15,4 \%$ dengan asumsi nilai variabel independen lainnya tidak berubah (konstan). Koefisien variabel motivasi ekonomi $\left(\beta_{3}\right)$ sebesar 0,149 , artinya apabila nilai variabel motivasi ekonomi mengalami kenaikan 1\%, maka minat mengikuti PPAK akan mengalami peningkatan sebesar 14,9\% dengan asumsi nilai variabel independen lainnya tidak berubah (konstan).

Berdasarkan hasil analisis regresi diamati Goodness of Fit-nya yaitu koefisien determinasi ( $\left.\mathrm{R}^{2}\right)$, uji F (uji kelayakanmodel), dan uji t (t test). 
Ni Made Anita Dwi Natami dan Ketut Muliartha. Pengaruh ...

Koefisien determinasi dilakukan untuk mengetahui seberapa banyak variabel bebas dapat menjelaskan variabel terikatnya. Besarnya nilai $\mathrm{R}^{2}$ ditunjukkan dengan nilai adjusted $R$ square. Nilai koefisien determinasi berada diantara kisaran nol sampai satu. Hasil koefisien determinasi dapat dilihat pada Tabel 8, sebagai berikut.

Tabel 8.

Hasil koefisien determinasi

\begin{tabular}{lrrrr}
\hline Model & R & R Square & Adjusted R Square & Std. Error of the Estimate \\
\hline 1 &, $762^{\mathrm{a}}$ &, 581 &, 574 & 1,836 \\
\hline Sumber: Data diolah, 2019 & & &
\end{tabular}

dapat dilihat bahwa nilai Adjusted $R$ Square pada model sebesar0,574. Nilai Adjusted $R$ Square pada model artinya variabel minat mengikuti PPAK dapat dijelaskan oleh variabel sikap, motivasi kualitas, dan motivasi ekonomi sebesar 57,4\%, sedangkan sisanya dijelaskan oleh variabel-variabel lain diluar model yang digunakan dalam penelitian ini yaitu sebesar 42,6. Standar Error of the Estimate atau SEE memiliki nilai 1,836, yang artinya semakin kecil nilai SEE akan membuat model regresi semakin tepat dalam memprediksi variabel independen. Pada Tabel 9 dijabarkan mengenai hasil dari uji F.

Tabel 9.

Hasil uji F (Uji kelayakan model)

\begin{tabular}{lrrrrr}
\hline Model & Sum of Squares & Df & Mean Square & F & \multicolumn{1}{c}{ Sig. } \\
\hline Regression & 776,758 & 3 & 258,919 & 76,803 &, $000^{\mathrm{a}}$ \\
Residual & 559,618 & 166 & 3,371 & & \\
Total & 1336,376 & 169 & & & \\
\hline Sumber: Data diolah, 2019 & & & & &
\end{tabular}

Setelah dilakukan pengujian kelayakan model didapatkan hasil bahwa model yang digunakan dalam penelitian ini memiliki nilai Sig. yaitu 0,00 yang berarti model yang digunakan dalam penelitian ini dinilai layak digunakan sebagai alat analisis variabel. 
Uji t dalam penelitian ini bertujuan untuk menguji apakah semua variabel bebas yang digunakan dalam model regresi memiliki pengaruh signifikan secara parsial terhadap variabel terikat. Hasil dari uji hipotesis ini dapat diambil kesimpulannya apabila nilai siginikansinya $>0,05$ maka hipotesis ditolak (koefisien regresi tidak signifikan), dan apabila nilai signifikansinya $<0,05$ maka hipotesis diterima (koefisien regresi signifikan). Tabel 10 menunjukkan hasil dari uji t.

Tabel 10. Hasil uji t ( t test)

\begin{tabular}{ccccc}
\hline Variabel & $\begin{array}{c}\text { Koefisien } \\
\text { Regresi }\end{array}$ & $\mathrm{t}_{\text {hitung }}$ & Sig. & Hasil Hipotesis \\
\hline Sikap (X1) &, 210 & 3,773 &, 000 & $\mathrm{H}_{1}$ Diterima \\
Motivasikualitas (X2) &, 154 & 3,073 &, 002 & $\mathrm{H}_{2}$ Diterima \\
Motivasiekonomi (X3) &, 149 & 2,815 &, 005 & $\mathrm{H}_{3}$ Diterima \\
\hline
\end{tabular}

Sumber: Data diolah, 2019

Berdasarkan hasil uji statistik t pada Tabel 10, dapat diinterpretasikan beberapa hal dalam penelitian ini, sebagai berikut. Hipotesis pertama menyatakan bahwa sikap memiliki pengaruh yang positif pada minat mengikuti PPAk. Pada Tabel di atas dapat dilihat bahwa nilai signifikansi uji t untuk variabel sikap sebesar 0,000 yaitu lebih kecil dari $\alpha=0,05$ dengan koefisien regresi bernilai positif sebesar 0,210. Berdasarkan hal tersebut, maka hipotesis pertama $\left(\mathrm{H}_{1}\right)$ dalam penelitian ini diterima. Artinya secara parsial sikap memiliki pengaruh yang positif pada minat mengikuti PPAk. Sikap merupakan bagaimana individu percaya tentang adanya konsekuensi dari setiap perilaku atau behavioral belief dan bagaimana seseorang mengevaluasi mengenai konsepuensi apa yang akan didapatkan yang merupakan hasil dari perilakunya atau outcome evaluation (Hartono, 2007:38). 
Pada Tabel di atas dapat dilihat bahwa nilai signifikansi uji t untuk variabel motivasi kualitas sebesar 0,002 yaitu lebih kecil dari $\alpha=0,05$ dengan koefisien regresi bernilai positif sebesar 0,154. Berdasarkan hal tersebut, maka hipotesis kedua $\left(\mathrm{H}_{2}\right)$ dalam penelitian ini diterima. Artinya secara parsial motivasi kualitas memiliki pengaruh yang positif pada minat mengikuti PPAk.

Berpengaruh positif disini berarti bahwa ketika motivasi kualitas yang dimiliki seseorang meningkat, maka minat mahasiswa untuk mengikuti Pendidikan Profesi Akuntan juga akan meningkat. Peningkatan ini dapat dikarenakan oleh adanya kesadaran dalam diri individu yang dalam penelitian ini adalah mahasiswa, untuk memiliki kuaitas diri yang lebih baik dengan meningkatkan kemampuannya dalam hal yang dijalaninya untuk tercapainya tujuan yang telah ditetapkan. Teori motivasi yang dikemukakan oleh McClelland mendukung hasil dari penelitian ini yang memberikan pernyatan bahwa prestasi yang dihasilkaan oleh seorang individu dapat dikarenakan adanya kesadaran pada diri individu tersebut untuk mengembangkan kemampuannya dan meningkatkan kualitas dalam dirinya (Robins dan Judge, 2008:87).

Penelitian ini konsisten dengan penelitian yang dilakukan oleh Fahriani(2012) yang menyatakan motivasi kualitas berpengaruh terhadap minat mahasiswa untuk mengikuti PPAk. Menurut Sapitri dan Yaya (2015) yang dalam penelitiannya juga menemukan bahwa motivasi kualitas memiliki pengaruh yang positif terhadap minat mahasiswa akuntansi mengikuti PPAk. Masih sejalan dengan temuan dari penelitian-penelitian sebelumnya, Raminten(2012) juga menemukan bahwa motivasi kualitas memiliki pengaruh yang positif pada minat 
mahasiswa untuk mengikuti program PPAk. Kesimpulannya adalah mahasiswa mempertimbangkan untuk mengikuti program PPAk untuk meingkatkan kualitas dirinya. Dengan memiliki kualitas yang baik mahasiswa memiliki keyakinan bahwa hal tersebut akan berdampak baik pada kinerjanya.

Pada Tabel di atas dapat dilihat bahwa nilai signifikansi uji t untuk variabel motivasi ekonomi sebesar 0,005 yaitu lebih kecil dari $\alpha=0,05$ dengan koefisien regresi bernilai positif sebesar 0,149 . Berdasarkan hal tersebut, maka hipotesis ketiga $\left(\mathrm{H}_{3}\right)$ dalam penelitian ini diterima. Artinya secara parsial motivasi ekonomi berpengaruh positif pada minat mengikuti PPAk.

Berpengaruh positif disini berarti bahwa ketika motivasi ekonomi yang dimiliki oleh seseorang semakin meningkat, oleh karena itu dari dirinya akan timbul minat untuk mengikuti Pendidikan Profesi Akuntan. Mahasiswa memiliki motivasi untuk mendapatkan imbalan finansial yang lebih tinggi dengan menambahkan kualitas dirinya yaitu denganmengikuti program PPAk. Temuan penelitian ini sejalan dengan teori Hierarki Maslow yang menyatakan bahwa setiap individu memiliki kebutuhan penghargaan untuk memenuhi kebutuhan sehari-hari seperti kebutuhan fisiologis untuk bertahan hidup. Dengan adanya kebutuhan yang harus dipenuhi oleh individu, maka imbalan finansial menjadi pertimbangan dalam pengambilan keputusan oleh individu tersebut. Imbalan finansial yang tinggi akan membuat individu tersebut tertarik untuk melakukan sesuatu yang dalam hal ini adalah individu melihat dengan mengikuti program PPAk, dan individu tersebut mengalami peningkatan kualitas maka kedepannya imbalan finansial yang didapatkan akan meningkat. 
Ni Made Anita Dwi Natami dan Ketut Muliartha. Pengaruh ...

Sesuai dengan penelitian Raminten (2012) dan Nisa (2012) yang menemukan bahwa motivasi ekonomi memiliki pengaruh yang signifikan terhadap minat mahasiswa mengikuti PPAk. Kesimpulannya adalah mahasiswa memiliki anggapan bahwa dengan mengikuti program PPAk maka profesionalisme yang dimilikinya akan meningkat dan dapat digunakan untuk mendapatkan penghargaan finansial yang diinginkan.

\section{SIMPULAN}

Sikap berpengaruh positif terhadap minat mahasiswa akuntasi untuk mengikuti PPAk. Sikap merupakan bagaimana individu percaya tentang adanya konsekuensi dari setiap perilaku atau behavioral belief dan bagaimana seseorang mengevaluasi mengenai konsekuensi apa yang akan didapatkan yang merupakan hasil dari perilakunya atau outcome evaluation

Motivasi Ekonomi berpengaruh positif terhadap minat mahasiswa akuntansi untuk mengikuti PPAk. Berpengaruh positif disini berarti bahwa ketika motivasi ekonomi yang dimiliki oleh seseorang semakin meningkat, oleh karena itu dari dirinya akan timbul minat untuk mengikuti Pendidikan Profesi Akuntan.

Motivasi Kualitas berpengaruh positif terhadap minat mahasiswa akuntansi untuk mengikuti PPAk. Berpengaruh positif disini berarti bahwa ketika motivasi kualitas yang dimiliki seseorang meningkat, maka minat mahasiswa untuk mengikuti Pendidikan Profesi Akuntan juga akan meningkat. 


\section{REFRENSI}

Ajzen, I. (1991). The Theory of Planned Behavior (Organizati).

Benny, Y. (2006). Pengaruh Motivasi terhadap Minat Mahasiswa Akuntansi untuk Mengikuti Pendidikan Profesi Akuntansi (PPAk), (Simposium Nasional Akuntansi 9, Padang.).

Besterfield, D. (2003). Total Quality Manajemen (Third Edit).

Cendrawi. (2015). Minat Mahasiswa Baru Program Studi Akuntansi Dalam Memilih Jurusan perkuliahan. Jurnal. Fakultas Ekonomi Dan Bisnis Universitas Brawijaya. Malang.

Chinowsky P. and Carillo P. (2006). Knowledge Management to Learning Organization Connection. Journal of Management in Engineering.

Fahriani, D. (2012). Pengaruh Motivasi Terhadap Minat Mahasiswa Akuntansu Untuk Mengikuti Pendidikan Profesi Akuntansi ( PPAk ), Jurnal Akuntansil(12), 1-22.

Felton et al. (1995). A theory of reasoned action model of the chartered accountan career choice. Journal of Accounting Education, 13(1):1-19.

Goetsch, D. L. D. S. B. D. (2002). Quality Managemnt, Introdction to Total Quality Management for Production, processing, and services (New Jersey).

Hadiprasetyo, T. (2014). Pengaruh Motivasi, Persepsi Biaya Pendidikan Dan Persepsi Masa Studi Terhadap Minat Mahasiswa Prodi Akuntansi Fakultas Ekonomi Universitas Negeri Yogyakarta Untuk Mengikuti Pendidikan Profesi Akuntansi. Jurnal Akuntansi Universitas Negeri Yogyakarta.

Hartono, J. (2007). Sistem informasi keperilakuan (Andi Offse). Yogyakarta.

Ikbal, M. (2011). Pengaruh Motivasi Terhadap Minat Mahaiswa Akuntansi Untuk Mengikuti Pendidikan PPAk: Studi Kasus Pada Mahasiswa Akuntansi Universitas Diponegoro Semarang.

Istina dan Yulita. (2014). Pengaruh Persepsi dan Motivasi Mahasiswa Jurusan Akuntansi Yang Sedang Mengambil Skripsi Terhadap Peminatan Karir Dalam Bidang Perpajakan. Jurnal Akuntansi.

Kamus Besar Bahasa Indonesia. (2008). Tim Penyusun Kamus Besar Bahasa Indonesia. (Edisi Pertama). Jakarta. 
Kusumastuti, W. dan. (2013). Permgaruh Motivasi dan Pengetahuan UU No.5 Tahun 2011 Tentang Akuntan Publik Terhadap Minat Mahasiswa Akuntansi Mengikuti Pendidikan Profesi Akuntansi (PPAk). Jurnal Nominal, II(5), 130 .

Mar'at. (2000). Sikap Manusia: Perubahan serta Pengukurannya. (Ghalia Ind). Bandung.

Meitiyah, A. (2014).Pengaruh Motivasi Terhadap Minat Sarjana Untuk Mendaftar Program Pendidikan Profesi Akuntansi (PPAk). Jurnal Akuntansi UniversitasHasanuddin.

Minan, K. (2011). Pengaruh Motivasi Terhadap Minat Mahasiswa Untuk Mengikuti Pendidikan Profesi Akuntan. Jurnal Keuangan Dan Bisnis Indonesia, 3(1).

Nisa, N. A. (2012). Faktor-Faktor yang Mempengaruhi Minat Mahasiswa Untuk Mengikuti Pendidikan Profesi Akuntansu (PPAk) Di Surakarta. (Survei. Jurnal Akuntansi Universitas Muhammadiyah Surakarta.

Novita, I. (2009). Motivasi dan Minat Mahasiswa Untuk Mengikuti Pendiidkan Profesi Akuntansi (PPAk). Pekbis Jurnal, 1(2), 124-130.

Raminten. (2012). Pengaruh Motivasi Terhadap Minat Mahasiswa Akuntansi Mengikuti Pendidikan Profesi Akuntansi ( Ppak ) Studi Empiris Pada Mahasiswa Program Studi Akuntansi Universitas Semarang. Juraksi, 1(2301-9328.).

Robins dan Judge. (2008). Perilaku Organisasi. (Alih B ahasa: Diana Angelica dkk, Ed.) (Slemba Empat). Jakarta.

Robins dan Judge. (2015). Perilaku Organisasi, Alih Bahasa (Slemba Empat). Jakarta.

Sapitri, Z., \& Yaya, R. (2015). Faktor-Faktor Yang Berpengaruh Terhadap Minat Mahasiswa Untuk Mengikuti Pendidikan Profesi Akuntansi ( PPAk ). Jurnal Akuntansi Universitas Muhammadiyah Yogyakarta.

Slameto. (2010). Belajar dan Faktor-faktor yang Mempengaruhinya (PT. Rineka). Jakarta.

Solikhah, B. (2014). An application of theory of planned behavior towards CPA career in Indonesia. Procedia - Social and Behavioral Sciences, 164(August), $397-402$.

Stole, S. D. (1976). Student's Views of The Public and Industrial Accountant. 
Journal of Accountancy, Pp:106-109.

Tella, A. (2007). The Impact of Motivation on Student's Academic Achievement and Learning Outcomes in Mathematics among Secondary School Students in Nigeria. Eurasia Journal of Mathematics, Science \& Technology Education, 3(2), 149-156.

Thomas et al. (1998). Quality Review, Continuing Professional Education, Experince and Substandart Performance. AN Emperical Study:Journal of Accounting Horizons, 12(4)

Undang-undang No.34 Tahun 1954 tentang Pemakaian Gelar Akuntan.

Widyastuti, dkk. (2004). Widyastuti, Suryaningsum dan Juliana. 2004. Pengaruh Motivasi terhadap Minat Mahasiswa Akuntansi untuk Mengikuti Pendidikan Profesi Akuntansi (PPAK). Simposium Nasional Akuntansi VII.

Wirawan, S. (1996). Pengantar Umum Psikologi. Jakarta: Bulan Bintange.

www.kompas.com. Diunduh pada tanggal 10 Oktober 2018 